\title{
Efficiency Assessment of Fuel Borne Catalyst
}

\author{
Marie Sejkorová ${ }^{1, *}$, Branislav Šarkan ${ }^{2}$, and Jan Verner $^{1}$ \\ ${ }^{1}$ University of Pardubice, Faculty of Transport Engineering, Department of Transport Means and \\ Diagnostics, Studentská 95, 53210 Pardubice, Czech Republic \\ ${ }^{2}$ University of Žilina, Faculty of Operation and economics of Transport and Communications, \\ Department of Road and Urban Transport, Univerzitná 1, 010 26, Žilina, Slovakia
}

\begin{abstract}
Fuel additives are offered to motorists at petrol stations and on the internet. Cerium or iron in the form of ferrocene is often used as a catalytically active metal in these additives. Producers of these fuels borne catalyst declare that their use will improve certain properties of engine. Therefore, in this paper are presented the result of testing and effects of these additives on the smoke and the engine noise. The results do not confirmed the positive effect of these fuel additives on the researched properties of engine.
\end{abstract}

\section{Introduction}

Thanks to the invention of the combustion engine, transport accelerated significantly and at the same time it has been enabled to transport people and goods for longer distances. Transport has therefore entered a new dimension of breaking the barriers. Nowadays, transport not only enables meeting people, connecting cultures and increase of economic and social functions but it has also become a significant factor influencing the environment. In 2012, the total share of emissions produced by the transport sector, including international transport, was $24 \%$. Transport is therefore the only sphere of the European Union (EU) where the emission has increased since 1990 [1]. Transport, especially road transport, is also the main producer of noise when considering the amount of inhabitants exposed to the noise levels exceeding hygienic limits. Approximately 210 million people in the EU are exposed to excessive noise caused by road transport. A study on the risk of the influence of excessive decibels on human health, which nearly a half of Europeans is exposed to, was published [2]. Unwanted excessive noise may aside from bad sleeping lead to e.g. development or worsening of lifestyle diseases such as high blood pressure or diabetes. According to World Health Organization noise above 55 decibels means serious discomfort and may set off development of many diseases and other disorders.

One of the possible ways how to reach an improvement in the area of road transport emission production is to use fuel catalytic converters. Fuel catalytic converters are organometallic compounds dissolved in organic carrier fluids. Their main contribution is supporting of diesel particulate filter (DPF) system functions. Fuel catalytic converters and diesel burn together in the combustion chamber and respective oxides develop from the metals present. These inorganic particles are subsequently diffused and are collected

*Corresponding author: Marie.Sejkorova@upce.cz 
on the DPF as a homogenous compound made of carbonaceous particles and metal oxide particles. Metal oxide particles which are diffused in the carbonaceous particles decrease the temperature of their combustion, i.e. DPF regeneration temperature. The advantage of these catalytic converters is a better combustion and therefore a lower development of hydrocarbons, carbon monoxide, and solid parts. The disadvantage may be the fact that their catalytic potential manifests during the fuel oxidation in the fuel tank itself [3]. A lot of studies reported the results of the metal oxide additives, e.g. aluminum oxides [4], copper oxides, manganese oxides or cerium oxides [5] in diesel. These compounds may lower e.g. the soot production thanks to strengthening the contact between the catalytic converter and soot [6]. Cerium $(\mathrm{Ce})$ or iron $(\mathrm{Fe})$ in the ferrocene form $\left(\left(\mathrm{C}_{5} \mathrm{H}_{5}\right)_{2} \mathrm{Fe}\right)$ are frequently used by catalytically active metals [7-9].

Ferrocene is an organometallic compound which used to be added into automotive gasoline for increasing the octane number. Ferrocene has never reached such popularity as lead antidetonators and some studies proved that iron oxides developing during ferrocene combustion increase the wear of the engine because of their abrasive effect, especially at cylinder walls and piston rings [4]. Based on the experimental studies, some researchers reached the conclusion that the addition of ferrocene prevents soot production. It has been proved that the addition of iron containing compounds increases the speed of soot oxidation and decreases the total soot amount by combustion [10]. Iron oxide particles function as a nucleation centers for soot production and these are subsequently oxidized by the $\mathrm{Fe}_{\mathrm{x}} \mathrm{O}_{\mathrm{y}}+$ $\mathrm{C} \rightarrow \mathrm{CO}+\mathrm{Fe}_{\mathrm{x}} \mathrm{O}_{\mathrm{y}-1}$ reaction [7].

Adding ferrocene into the motor diesel has an impact on the process of soot production and the molecular structure and nano-structure of soot. According to the data [11], it appears that the carbon structure of soot changes dramatically in favor of aliphatic structures. With regards to the fact that the motor diesel and ferrocene compound produces soot with a less graphitic yet more aliphatic structure, it may be one of the ways for increasing the soot oxidation. Nevertheless, with regards to respiratory toxicity of iron oxides [11] which may be present in soot and ash, subsequent filtration of exhaust fumes is necessary in order to prevent the release of toxic substances into the air.

Cerium oxide is an extraordinary catalytic converter thanks to its ability to alter between two oxidation states, i.e. $\mathrm{CeO}_{2}(+4)$ and $\mathrm{Ce}_{2} \mathrm{O}_{3}(+3)$ using a relatively low energy reaction [12]. At the same time, cerium oxide lowers emissions of $\mathrm{HC}$, soot, and $\mathrm{NO}_{\mathrm{x}}$ in the exhaust fumes of combustion engines because of this unusual transformation ability. Cerium oxide is theoretically and experimentally proved redox catalyst used for decreasing harmful emissions of diesel engines.

Fuel catalyst converters may be in a liquid or solid form. These additives, which are added directly into the fuel tank, may be e.g. in the form of tablets. Manufacturers of these products claim reduction of pollutants in exhaust gases, decreasing of fuel consumption, increasing of engine performance, and a cleaning effect for the fuel system and combustion chamber.

Zhnag et al. [13] were researching the influence of cerium oxide based nanoparticles additive dosage of Envirox in diesel, engine performance, and emissions of polluting substances. Using this additive led to an improvement of the fuel effectivity of up to $5.6 \%$, $\mathrm{CO}_{2}$ emission reduction of $10.6 \%$, and reduction of solid particles of $24.4 \%$, but also an increase in ultrafine particles of $32 \%$, and a $\mathrm{NO}_{\mathrm{x}}$ increase of $9.3 \%$. Sajeevan and Sajith [14] and Sajith et al. [15] state that when using cerium oxide based nanoparticles as an additive into motor diesel, an average reduction of $\mathrm{H}_{\mathrm{x}} \mathrm{C}_{\mathrm{y}}$ emissions of $45 \%$ was found [15]. As a part of the study [3], the liquid product Envirox underwent and X-ray fluorescence (XRF) analysis which did not prove the presence of cerium nor any other metal and it was subsequently stated that it was only a hydrocarbon product. 


\section{Materials and methods}

The "Power Cab Tab" product by Aquel Bohemia, s.r.o. distributor was selected to be the fuel conditioner tested. This product in the form of tablet is widely known among the public and it is the best-selling fuel conditioner. This producer also claims this product causes noticeable differences in the behavior of the engine after a relatively short time of using this product.

The application of the tablets was always done immediately before refueling as stated by the producer of the fuel conditioner. The reason for this application is to prevent the tablet from getting stuck e.g. in the filler pipe of the fuel tank. One whole tablet is meant for 401 of automotive gasoline or diesel. In total, 9 tablets were used and 346.51 of fuel were taken in. The vehicle used in the experiment was a Škoda, Octavia II Combi $4 \times 4$ car. For the car parameters, see Tab 1. The table shows the initial state of kilometers or the state of the mileage until the first measuring (measuring without the use of fuel conditioner) and the subsequent state which means the state of the counter when the second measuring was conducted, i.e. after the fuel conditioner application. The distance driven between the first and the second measuring is 4,476 kilometers.

Table 1. Basic vehicle parameters. Source: authors

\begin{tabular}{|l|c|}
\hline Vehicles & Škoda Octavia II Combi 4x4 \\
\hline Engine & diesel engine, 1.9 TDi, $77 \mathrm{~kW}$, typ BXE \\
\hline Fuel & diesel \\
\hline Year of production & 2008 \\
\hline Type of emission system & Controlled with OBD, oxidation catalyst, without DPF \\
\hline Initial kilometres $[\mathrm{km}]$ & 282028 \\
\hline Total distance $[\mathrm{km}]$ & 4476 \\
\hline
\end{tabular}

The measuring of smoke emission was conducted in a specialized laboratory for measuring emissions. The measuring itself and its evaluation was conducted using the equipment shown in Tab 2. The period during which the tablets were being applied was 3 months. The producer claims that an improvement of the parameters measured should manifest during this period.

Table 2. Used equipment. Source: authors

\begin{tabular}{|l|l|}
\hline Place of measurement & $\begin{array}{l}\text { ZDAR, a.s. (Technical inspection Žd'ár nad } \\
\text { Sázavou) }\end{array}$ \\
\hline Used equipment for measurement emission & $\begin{array}{l}\text { opacimeter MAHA MDO - 2; } \\
\text { Software DEKRA Emissions (2016.0.3) }\end{array}$ \\
\hline Used equipment for measurement sound & sound level meter VOLTCRAFT 322 Datalog \\
\hline The time difference first and second measurements & 3 month \\
\hline
\end{tabular}


The measuring was conducted according to the methodical procedure of emissions measuring approved by the Ministry of Transport of the Czech Republic. Before the smoke emission measuring itself, an engine diagnosis with the inclusion of the error log which was without any entry. The value of the corrected absorption coefficient, which is given by the producer and which must be subsequently followed by the vehicle, was generated automatically by an on-line measuring tool. It is the maximum value possible which guarantees fulfillment of the emission requirements. In this case it was $1.00 \mathrm{~m}^{-1}$.

The noise measuring was conducted at the same time as the smoke emission measuring for the sake of following the identical conditions of the experiment.

Initially, the first measuring was conducted for finding the noise values of the engine using diesel without additives and subsequently second measuring after the application of fuel with fuel conditioner added during the testing period in real running conditions, i.e. for three months.

The microphone was placed at the height of $1.1 \mathrm{~m}$ and in the middle in front of the vehicle with an open hood in the distance of $0.2 \mathrm{~m}$. There were not any reverberation obstacles in the immediate surrounding area. The measuring is shown in Fig. 1. All measuring parameters are shown in Tab 3.

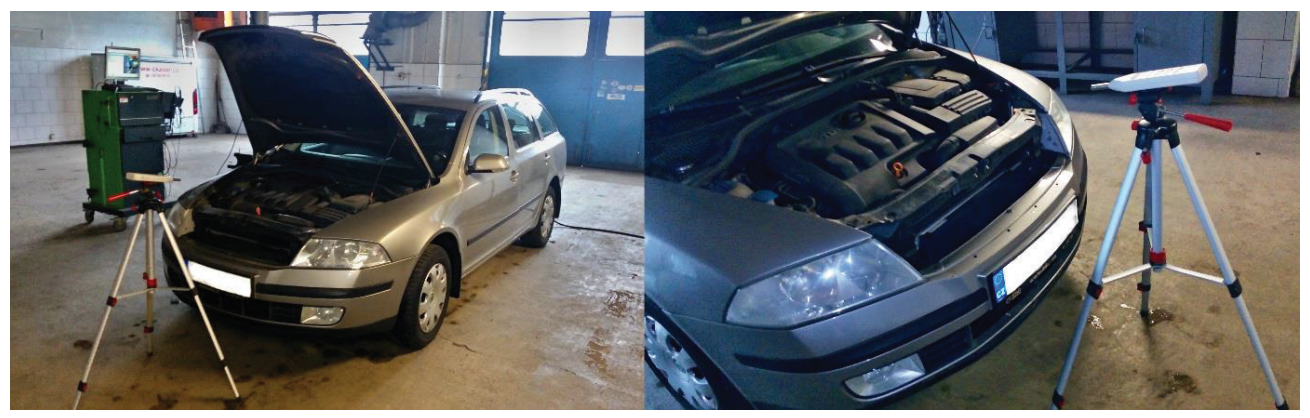

Fig. 1. Measurement of engine noise. Source: authors

Table 3. Results from measurement of noise. Source: authors

\begin{tabular}{|l|c|c|}
\hline & 1st measurement & 2nd measurement \\
\hline used equipment for measurement sound & sound level meter VOLTCRAFT 322 Datalog \\
\hline used weighting filter & weighting filter A \\
\hline $\begin{array}{l}\text { the height of the microphone from the floor }[\mathrm{m}] \\
\text { distance of microphone from vehicle in top view } \\
{[\mathrm{m}]}\end{array}$ & \begin{tabular}{c}
1.1 \\
\hline $\begin{array}{l}\text { microphone placement relative to vehicle } \\
\text { bonnet open }\end{array}$
\end{tabular} \\
\hline $\begin{array}{l}\text { distance of the nearest object [m] } \\
\text { distance of other objects [m] }\end{array}$ & \begin{tabular}{c} 
front part, at the center of the vehicle with the \\
\hline
\end{tabular} & $>6.5$ \\
\hline
\end{tabular}




\section{Results and discussion}

Value of $1.11 \mathrm{~m}^{-1}$ was obtained by the measuring of the smoke emission conducted at the technical inspection of the ZDAR, a.s., Žd'ár nad Sázavou company at the beginning of the experiment, i.e. without the use of fuel conditioners, as seen in an excerpt from the protocol shown in Tab 4.

Table 4. 1st measurement (before using the conditioner fuel). Source: authors

\begin{tabular}{|c|c|c|c|}
\hline \multirow{2}{*}{\multicolumn{2}{|c|}{ results check of the readiness code }} & \multicolumn{2}{|c|}{ set } \\
\hline & & \multicolumn{2}{|c|}{ Mil: off } \\
\hline \multicolumn{2}{|c|}{ the result of check of the engine control unit } & \multicolumn{2}{|c|}{ without error } \\
\hline engine speeds & predefined speed & \multicolumn{2}{|c|}{ measured } \\
\hline idling & $800-1000$ & \multicolumn{2}{|c|}{830} \\
\hline overrun & $4650-5050$ & \multicolumn{2}{|c|}{4850} \\
\hline \multicolumn{2}{|c|}{ corrected absorption coefficient by the label $\left[\mathrm{m}^{-1}\right]$} & \multicolumn{2}{|c|}{1.00} \\
\hline \multicolumn{2}{|c|}{ value of smoke $\left[\mathrm{m}^{-1}\right]$} & \multicolumn{2}{|c|}{1.11} \\
\hline \multirow{2}{*}{\multicolumn{2}{|c|}{$\begin{array}{l}\text { smokiness range of values of four consecutive } \\
\text { measurements }\left[\mathrm{m}^{-1}\right]\end{array}$}} & permissible & 0.25 \\
\hline & & measured & 0.00 \\
\hline
\end{tabular}

After three-month-long using of Power Car Tab fuel conditioner when the second measuring was conducted, the value of $1.08 \mathrm{~m}^{-1}$ was obtained (see Tab 5). With regards to the fact that $1.00 \mathrm{~m}^{-1}$ is the maximum limit allowed, the vehicle could not be approved as capable of operation on the roads of the Czech Republic in case of emission measuring and being a subject to a subsequent vehicle inspection.

Table 5. 2nd measurement (after using the fuel conditioner). Source: authors

\begin{tabular}{|c|c|c|c|}
\hline \multirow{2}{*}{\multicolumn{2}{|c|}{ results check of the readiness code }} & \multicolumn{2}{|c|}{ set } \\
\hline & & \multicolumn{2}{|c|}{ Mil: off } \\
\hline \multicolumn{2}{|c|}{ the result of check of the engine control unit } & \multicolumn{2}{|c|}{ without error } \\
\hline engine speeds & predefined speed & \multicolumn{2}{|c|}{ measured } \\
\hline idling & $800-1000$ & \multicolumn{2}{|c|}{830} \\
\hline overrun & $4650-5050$ & \multicolumn{2}{|c|}{4860} \\
\hline \multicolumn{2}{|c|}{ corrected absorption coefficient by the label $\left[\mathrm{m}^{-1}\right]$} & \multicolumn{2}{|c|}{1.00} \\
\hline \multicolumn{2}{|c|}{ value of smoke $\left[\mathrm{m}^{-1}\right]$} & \multicolumn{2}{|c|}{1.08} \\
\hline \multirow{2}{*}{\multicolumn{2}{|c|}{$\begin{array}{l}\text { smokiness range of values of four consecutive } \\
\text { measurements }\left[\mathrm{m}^{-1}\right]\end{array}$}} & permissible & 0.25 \\
\hline & & measured & 0.00 \\
\hline
\end{tabular}

In both cases presented, diesel was refueled at the same authorized company which is supposed to sell fuel following the requirements given by the Czech legislation. Using fuel conditioners in the form of tablets reduced the smoke emission by $0.03 \mathrm{~m}^{-1}$; value of 1.00 $\mathrm{m}^{-1}$, which is the limit for compliance of the emission limits, was not reached.

The difference of the average measured noise values of the engine with idle speed between the first and the second measuring is $0.3 \mathrm{~dB}$. In the case of overrun speed, the 
difference was $0.4 \mathrm{~dB}$, as shown in Tab 6 . The measuring accuracy of the noise meter used is $\pm 1.5 \mathrm{~dB}$. The results measured do not meant conclusive reduction of engine noise claimed by the tablet producer.

Table 6. Results of noise measurement. Source: authors

\begin{tabular}{|l|c|c|}
\hline & 1st measurement & 2nd measurement \\
\hline \multirow{2}{*}{ Max noise at idling speed for 30 seconds [dB] } & 72.1 & 71.7 \\
\cline { 2 - 3 } & 71.9 & 71.8 \\
\cline { 2 - 3 } $\begin{array}{l}\text { The average value of max noise at idling speed for 30 } \\
\text { seconds [dB] }\end{array}$ & 72.0 & 71.6 \\
\hline \multirow{2}{*}{ Max noise at overrun engine speeds for 5 s [dB] } & 72 & 71.7 \\
\cline { 2 - 3 } & 101.9 & 101.6 \\
\hline $\begin{array}{l}\text { The average value of max noise at overrun engine } \\
\text { speeds for 5 seconds [dB] }\end{array}$ & 101.7 & 101.4 \\
\hline
\end{tabular}

\section{Summary and conclusion}

Using the fuel based catalyst converter is one of the ways how to reduce pollutant emissions from combustion engines. Fuel additives are additives into the fluid hydrocarbon fuel which are supposed to influence their quality or improve combustion. The producers of fuel conditioners claim the products improve engine characteristics such as higher performance, lower fuel consumption; production of pollutant emissions lowered by $90 \%$, noise reduction and higher engine protection. The question is if it is not only a business stunt of the producers of the additives. Because of this, emission measuring and noise measuring of a Škoda Octavia car with and without fuel conditioner was conducted. The fuel conditioner selected was Power Car Tab.

Using of the aforementioned conditioner lasted for the period of three months and with range of $4,476 \mathrm{~km}$. All requirements for unambiguous recognition of the functionality of the additives defined by the producer were therefore met. However, the differences of emission and noise measuring before and after the application of fuel conditioner did not confirm the producer's positive claims; the smoke emission was reduced only by $0.03 \mathrm{~m}^{-1}$, the noise values decreased only by $0.3 \mathrm{~dB}$, or $0.4 \mathrm{~dB}$, respectively.

The results of this thesis are in accordance with the research results [3] which observed the changes in oxidative stability of fuels during using of fuel conditioner and it also did not prove any positive effect of fuel conditioner application.

This study is partly funded by the University of Pardubice (No. SGS_2017_009).

This paper is supported by the research project "From horse-drawn railway to intermodal transport" within Visegrad Fund. 


\section{References}

1. Evropská agentura pro životní prostředí, Evropské životni prostředi - stav a výhled, 212 (2015)

2. LC Den Boer, A. Schroten, CE Delft 70 (2007)

3. J. Černý, P. Šimáček, Úsporné tablety do paliva - obchod s lidskou důvěřivostí, Kniha přednášek mezinárodni konference Tribotechnika v provozu a údržbě 2016, 9-14 (VŠB - Technical University of Ostrava, Czech Republic, 2016)

4. M.J. Kao, B.F. Lin, T.T. Tsung, 18th Internal Combustion Engine Symposium (Jeju, Korea, 2005)

5. A.M.V. Selvan, R.B. Anand, M. Udayakumar, Fuel 130, 160-167 (2014), DOI: 10.1016/j.fuel.2014.04.034

6. J. Lahaye, et al, Combustion and Flame 104, 1-2, 199-207 (1996), DOI: 10.1016/00102180(95)00176-X

7. CH. HU, et al, Journal of the Energy Institute (2016)

8. A.C. Sajeevan, V. Sajith, Fuel 183, 155-163 (2016), DOI: 10.1016/j.fuel.2016.06.048

9. K. Tian, Z.S. Li, S. Staude, B. Li, Z.W. Sun, A. Lantz, M. Aldén, B. Atakan, Proceedings of the Combustion Institute 32, 1, 445-452 (2009)

10. J. Zhang, C.M. Megaridis, Combustion and Flame 105, 4, 528-540 (1996)

11. Z.H. Zhang, R. Balasubramanian, Environmental Science \& Technology 51, 8, 42484258 (2017), DOI: 10.1021/acs.est.7b00920

12. A. Trovarelli (ed.), Catalysis by ceria and related materials (World Scientific, 2002)

13. J. Zhang, et al, Environmental science \& technology 47, 22, 13077-13085 (2013), DOI: $10.1021 / \mathrm{es} 402140 \mathrm{u}$

14. A.C. Sajeevan, V. Sajith, Journal of Engineering 2013, 1-9 (2013), DOI: $10.1155 / 2013 / 589382$

15. V. Sajith, C.B. Sobhan, G.P. Peterson, Advances in Mechanical Engineering 2010, 1-6 (2010), DOI: $10.1155 / 2010 / 581407$ 